\title{
An overview of liberation theology in orthodox Russia
}

\author{
Alexander I Negrov ${ }^{1}$ \\ Rector, St Petersburg Christian University (Russia) \\ Extraordinary Lecturer: Department of New Testament Studies \\ University of Pretoria
}

\begin{abstract}
The aim of this article is to demonstrate the presence of a theological system of socio-critical and socio-pragmatic strands within Russian Christianity at the beginning of the twentieth century. The political and social situation in Russia at that time was reflected in a reading of the New Testament that went far beyond the more customary ecclesiastic, dogmatic and ethical issues that had traditionally concerned Russian Orthodox theology. Among the Orthodox thinkers there were two camps that focused on antioppression issues. Some combined these issues with the liberationist ideology of the Russian Marxists and Socialists; while the other regarded these liberation movements as an anti-Christian way of interpreting Christianity. This article further claims that certain modern developments in Liberation Theology can be found in the period during which the Russian religious thinkers attempted to develop a theological perspective which paid attention to the social and political dimensions inherent in social democracy (Marxism).
\end{abstract}

\section{INTRODUCTION}

In recent decades, there has been a proliferation of literature on the issues of political domination and the social oppression of the poor or of groups of people who share a particular ethnic, racial, or religious background on the one hand, and on emancipation from colonial powers on the other. During the last decades of the $20^{\text {th }}$ century, Christians have increasingly contributed to the debate, and have become more active in the struggle against various kinds of discrimination and injustice. In contemporary theology, these efforts

\footnotetext{
${ }^{1}$ A short version of this article was presented in a paper read at the annual meeting of the New Testament Society of South Africa, held from 9-12 April 2002, at the North West University (Potchefstroom Campus). Dr Alexander Negrov is the Rector of the St Petersburg Christian University (Russia) and a research associate of Prof Dr Jan G van der Watt, Department of New Testament Studies, Faculty of Theology, University of Pretoria.
} 


\section{A forecast of liberation theology in the orthodox Russia}

have come to be described as liberation theology, a term which links the social, political and economic issues and theories of a particular historical setting with a Christian theological dimension. The term is used to designate a range of theological approaches which give a central place to the concept of "praxis" and require the use of sociological, anthropological and historical analysis, in addition to a theological approach. The most conspicuous examples of a plural family of liberation theologies are "Feminist Theology", "Black Theology", "African Theology" and "Minjung Theology" (for a selected bibliography on liberation theology, see Rowland 1999:252-256).

The term "liberation theology" and a theological interpretation of liberation or salvation was first explicitly used in Latin America in the 1970s by Ruben Alves and Gustavo Gutierrez to describe a theological perspective that suggests that the concept of salvation has social and political dimensions (see Gutierrez 1973; Segundo 1976). In 1971, Gustavo Gutierrez offered the first systematic articulation of this view in his Teologia de la Liberacion [ $A$ Theology of Liberation] (Gutierrez 1973). Consequently, liberation theology is usually identified with the movement initiated in Latin America and was originally linked with the names of Gustavo Gutierrez, Ruben Alves, Hugo Assmann, Juan Luis Segundo, José Miguez Bonino, Leonardo Boff, Jon Sobrino, and other Catholic and Protestant theologians in the 1960s and 1970s (for sources on Latin American Liberation Theology see Jordan 1986:32-39).

The term "liberation theology" itself is a recent one. However, there is a long biblical and Christian tradition in which salvation by God was held to include not only deliverance from evil spirits, guilt, sin, sickness and eternal damnation, nor solely, as in other religions, a release from "the prison of the body" or from the domination of passion, but also a liberation from the power of the enemy, bondage, political domination or social oppression. Thus, I agree with Rowland (1999:11) that "Liberationist perspectives have a long pedigree in Christian theology".

In the technical sense, the term "liberation theology" cannot be used to identify the religious-revolutionary movements in Russia at the end of the nineteenth and start of the twentieth centuries. Nevertheless, I would argue that the data on that era demonstrate the presence of elements of a theological system of socio-critical and socio-pragmatic strands and indicate that such strands already existed in Russia at the start of the twentieth century.

The political and social situation in Pre-Revolutionary Russia resonated with a reading of the New Testament that went far beyond the more customary ecclesiastic, dogmatic and ethical issues that had traditionally concerned Russian Orthodox theology. The new reading penetrated to beneath the more immediate religious level of the New Testament to expose 
the role of New Testament texts as instruments of power, domination or social manipulation within the existing social and political order. Such a hermeneutic model stressed both the religious and the social significance of Scripture and revealed a boundary beyond which the issues of socio-contextual pragmatism were welcomed as a topic for discussion. I would argue that a number of elements of modern Liberation Theology can already be found in the works of those Russian religious thinkers who paid attention to the social and political dimensions inherent in Russian Social Democracy (Marxism). ${ }^{2}$

\section{THE POLITICAL AND RELIGIOUS BACKDROP OF PRE- REVOLUTIONARY RUSSIA}

The years preceding the revolution of 1917 in Russia were marked by many political events that affected the coming political, economic and social upheaval. Several movements aimed to overthrow the repressive tsarist rule, under which the country as a whole and most of the population suffered harsh economic and social conditions (see Galai 1973). There was an emphatic policy of Russification. Vladimir Lenin (1870-1924), Russian revolutionary leader and theorist, comments on this trend as follows: "A movement for national liberation flared up among the oppressed peoples of Russia. Over one-half, almost three fifths (to be exact, 57 per cent) of the population of Russia is subject to national oppression; they are not even free to use their native language, they are forcibly Russified" (Lenin 1964:249). Some "nonRussians" (especially the Jews) were treated especially badly. For an oppressed people whose self-determination had been denied and whose very existence had been challenged, these issues came to play a special role. In addition to these issues, there were also some attempts to explore changing gender relations in the wake of the emergence of women's liberation movements (see Stites 1991; Edmondson 1984:26-58), and other issues.

At different times various members of Russian society attempted to overthrow the oppressive tsarist government. Finally, in 1917, these attempts culminated in the overthrow of the imperial regime and the establishment of a new socialist economy and state. Throughout those years of oppression and attempts at resistance, various different ideological and political groups emerged and developed. Among them were the Mensheviks (pure Marxists), the Bolsheviks (Neo-Marxists) and other socio-political groups. All these groups disseminated ideas and information for the purpose of inducing or

\footnotetext{
${ }^{2}$ Among the most important works that discuss the relationship and interaction between Russian Orthodox theological thought and the socio-political situation in Russia see Berdyaev (1937); Spektorskii (1925); Frank (1988); Alexyev (1930); Zen'kovsky (1955); Stepun (1936); Fedotov (1957) and Verhovskoy (1953).
} 


\section{A forecast of liberation theology in the orthodox Russia}

intensifying particular attitudes and actions in Russian Society that would be conducive to the aims of these groups. The ideas were mainly defended or attacked on the basis of either secular ideology (by Marxists) or a Christian world-view (by religious-philosophical groups).

The philosophical awakening in nineteenth century Russia had a profound influence on the intellectual and religious climate in that country. Many of the Russian philosophers and thinkers were at the same time noted theologians (or vice versa). That is why prominent Russian Orthodox historian George Florovsky (1979) connects the history of Russian philosophical thought and the course of Russian Orthodox theology. The Russian religious philosophy of that period was devoted to the goals of a practical transformation of life and society and to a recognition of God as the substantial factor (see the standard books on the topic Berdyaev 1946; Losskii 1952; Zen'kovsky 1991). The questions of social ethics and political philosophy, of an individual's relationship to the Russian State, of sufficient knowledge and virtuous behaviour, of wisdom and power, of religious and aesthetic values, of ideas and ideals as guidelines for human life - all these were central to Russian religious philosophy.

These issues were especially clearly reflected in the formal encounters between Orthodox theologians and religious philosophers in Moscow and St Petersburg. The Religious-philosophical Meetings revealed differences between the philosophical and Orthodox ideological views, especially on issues and questions of social ethics, political philosophy and an individual's relationship to the State. On some points, the view of Church officials was contrary to the thinking of the Russian intelligentsia (a class of educated intellectuals, many of whom were the Orthodox laity). On the other hand, the religious philosophers accused the Orthodox Church of (1) lacking religioussocial concepts; (2) being concerned only with life beyond the grave (and therefore not stressing the relevance of the message of Christ for contemporary Russians and not converging with the needs of the people); and (3) protecting the monarchy as the only option for the Russian State (cf Ternavtsev 1906:7-42).

Subsequent religious-philosophical meetings, conducted by the newly instituted Religious-Philosophical Society (1907-1917) in St Petersburg and theVladimir Solov'ev Memorial Religious-Philosophical Society (1905-1918) in Moscow, debating questions and issues suggested by "the philosophical coalition", had became unsympathetic toward "the Church party" (cf Kartashov 1908:2). The relationship between the Church and Russian philosophical thought became increasingly fragile. The philosophers of the so-called "new religious conscience" suggested that there was no true Church and opposed 
the dogmatism of the Church by stating that reasonable philosophy is contra to the idea of revelation from above. The radical socialist-philosophers started "to conduct antichurch agitation" (Bronnikova 1993:121). At the same time, the religious philosophers emphasized that "the light, which comes upon the highest leaders of organized religion must shine toward the lower horizons of the society" (Berdyaev 1989:39). In other words, the religious thinkers stressed a contextualisation of Church actions and a shift from a purely religious piety (a customary activity) to an innovative programme of Church influence regarding the existing issues in nineteenth century Russian society and the State (on the religious focus and themes in Russian philosophy, also see Vyascheslavtzev 2002).

As a result, all the religious energy inherent in the Russian people was directed to socialism and to the issue of revolution. The works of the Russian religious thinkers present lively discussions on very pertinent, burning themes of the religious-philosophic, the religious-cultural, and the religious-social debates of the time.

In the gatherings of the Religious-Philosophic Society in memory of VI. Solov'ev at Moscow, the chief figure was the Russian Orthodox theologian Fr. Sergius Bulgakov (1871-1944), who was then not yet a priest, but a professor of political economics at the Commerce Institute. Later, the Religious-

Philosophic Society was founded on Nikolai Berdyaev's (1874-1948) initiative in St Petersburg. These societies were one of the expressions of the spiritual and theological unrest, and they became transmitters of the thoughts of that time.

The Russian theological renaissance of that time had several components. As strange as this may be at first glance, one of its well-springs was Russian Marxism at the end of the 1890s. Berdyaev was one of the spokesmen of the interconnectedness of and transition from Marxism to idealism, and then to Christianity. This tendency was represented by $S$ Bulgakov (1906:118-127; 1968; 1991), N Berdyaev, P Struve (on Struve's positions, see Pipes 1970), Semyon Frank (1877-1950) and several others. In the view of some Russian thinkers, Marxism, in terms of its very character, was inclined towards the construction of broad and totalistic historicosophistical concepts according to which social reforms must be made on purely secular grounds (Streletskii 1904:393). For others, Marxism was a peculiar sort of theology and they projected their own religious instincts onto it. So, for example, in Berdyaev's first book, Sub'ektivizm i individualizm v obschestvennoi filosofii [Subjectivism and Individualism in Social Philosophy], which came out in 1900, he attempted to construct an integrated synthesis of Marxism and idealism. 
Some of the Russian religious philosophers were directly connected to revolutionary circles. Their interest in Marxist categories was not related to Marx's holistic plan of political action, but only to Marxist categories for social analysis. Together with Marx, the Russian religio-philosophical thinkers of the nineteenth century believed that history was inescapably moving toward a climactic day when the oppressed workers of the world, the proletariat, would rise up and overthrow their capitalistic oppressors, the bourgeoisie. In the place of the old bourgeois society with its classes and class antagonisms, there would be a harmonious society in which there is equity for all. Some believed that this economic paradise would be achieved by purely materialistic enterprise, such as political reforms, state economic growth, etc. For many Orthodox theologians, however, such a position was unacceptable (Polozov 1903).

\section{SOME ESSENTIAL THEOLOGICAL AND PHILOSOPHICAL NOTIONS OF THE TIME}

The late nineteenth and beginning of the twentieth centuries were to be a great epoch, the age of the blossoming of Russian spiritual culture and an age of great Russian literature. In this period, Russian thought was expressed in the writing of Petr Chaadaev (1794-1856), Ivan Kireevsky (1800-1856), Alexey Khomiakov (1804-1860), Konstantin Leont'ev (1831-1891), Nikolai Fedorov (1829-1903) and many others. Drawing on Orthodox theology and Marxism, these and other theologians and thinkers developed their own theology by radically reinterpreting Scripture with a bias toward the poor and oppressed. Let us now briefly survey the key aspects of their theology.

Russian religious thought in the late nineteenth century is remarkable not for the completeness of its written works, but for its religious stimulation and its investigation of Christian freedom. Alexey Khomiakov and Fiodor Dostoevsky (1821-1881) were the chief heralds of Christian freedom. For them, there is to be no Church hierarchy; the Church is not an authority; even God Himself is not a figure of authority. Dostoevsky, who was the greatest of our religious thinkers, demonstrates in Legenda velikogo inkvizitora [The Legend about the Grand Inquisitor] that Christ represents freedom of the spirit, whereas the Anti-Christ is a negation of freedom. For Dostoevsky and others, freedom is not a right, but rather a responsibility of Christianity.

The idea of Sobornost', of communality, was another idea affirmed in Russian religious thought, alongside the idea of freedom. Sobornost' is a form of religious collectivism that requires from each and everyone both freedom of spirit and of conscience, without which it would not exist. Sobornost' is a characteristic that describes the wholeness of the people, but differs from the human idea of corporate body or commonness. The teaching about 
Sobornost' was first expressed by Khomiakov. ${ }^{3}$ Khomiakov sketched out an ideal image of the Church in all of Russian society. His theology stressed a sacramental community, comprised of both the living and the dead, filled by the Holy Spirit, and united with Christ by love, perfectly free, not knowing any sort of compulsion or external authority. It was an expectation and seeking out of the commencement of the Kingdom of God in Russia (see Khomiakov 1900-1906; on Khomiakov, in this respect, see Christoff 1961).

This brings us to yet another feature of the Russian religious thought of the twentieth century - an active prophetic spirit with an intense seeking of the Kingdom of God. On the one hand, that propheticism has raised the very disturbing problem of the possibility of new revelations, of dogmatic developments within the Church, of a creative process within Christianity. On the other hand, it has focused the need for a new religious consciousness - a new attitude of Christianity towards the world, a transfiguration by Christianity of all the fullness of life, the continuation of the God-incarnation process within history, the understanding of Christianity as the religion of God-(hu)manhood. Especially in the works of Nikolai Fedorov (see 1995-2000), the prophetic role of the Church was not depicted as a passive expectation of the end of the world and the Second Coming. It called for the Christianization of the world and for the activity of humans in the world. He boldly interprets the apocalyptic prophecies as a conditional threat: the world is to end; there will be the Dreaded Last Judgment and the eternal perishing of many, if humankind does not unite itself for the common task of the revival of the ordering of world life, both social and religious.

Russian theological thought at the end of the nineteenth century was very social in its focus. The earliest Russian revolutionaries were not politicians - they were tormented by questions about God, about immortality, the ultimate fate of humankind and the world. For many orthodox thinkers, social truth on Russian soil had to be realized, either through monarchy or through anarchy. Hidden behind these social utopias was the search for the Kingdom of God. Russian thinkers attempted to find a path for Russia which might avoid the development of capitalism with its inevitable triumph in the spiritual, moral and socio-economic spheres. Some of these thinkers

\footnotetext{
${ }^{3}$ Sobornost' (a non-equivalent term to other European languages) is a specific term that is based on the text of a late medieval Slavonic revision of the creed of NecaeaConstantinople. In designating the Church, the term kafolicheskaia was changed for sobornaya for example gathered together. Since that time, the term was used to depict the essence of a national church policy. In Russian philosophy, firstly, this term was used by Khomiakov (1900, vol 8:318). Later, K S Askakov used it for the description of the common spirit of the people united by one ideal [like socialism] (see Zen'kovskii, 1991: Vol 1, part 2, 18. Frank (1988:58-58) used the term to designate the inner element needed for the unity of public and family life.
} 


\section{A forecast of liberation theology in the orthodox Russia}

associated themselves with socialists (for more on this see Akvilonov 1906; Ern and Sventsitskii 1905b).

It is important to note that, among the Russian Orthodox thinkers who associated themselves with the socialists there was an understanding that socialism can be perceived exclusively as the social-economic organization of society. They still felt that it is the Church that wants to create a new man, a new brotherhood of people with its own relationship to the whole of life.

Through socialism, it was suggested, it was possible to create a new classless society, in which there would be a realization of great social justice and in which the exploitation of one human being by another human being would not be permitted (Kratirov 1916:991). The creation of the new man and the brotherhood of people, however, is a spiritual and religious task. It presupposes an inner regeneration of people. For some Orthodox thinkers a Christian can be a socialist, and even, as in Berdyaev's conviction, "ought to be a socialist" (Berdyaev 1935:3-19). Then, he or she ought to desire the socialization of the economy, which would (1) guarantee that every human has the right to work; (2) secure for every human being the possibility of realizing the fullness of life; (3) regulate the community by promoting communication between people on the issue of justice. However, they believed that it is only the Church that is able of itself to create a new man or a brotherly community of people, to create community, communion between people, and the brotherhood of people.

\section{THE CHURCH AND REVOLUTION}

The revolutionary ideas of Orthodox people were revealed clearly after the events on what came to be called Bloody Sunday (9 January 1905), when demonstrating students and labourers, led by Socialist groups and by Georgii Appolonovich Gapon, a revolutionary Orthodox priest, marched to the Winter Palace to present their social and political demands. They were fired on by imperial troops; hundreds were killed and wounded. Such violent preservation of political stability in the country became the subject of public debate (for an account of the immediate pre-Revolution period, see Curtiss 1940 and Simon 1973:199-235).

This massacre was a match setting off a revolution (cf Read 1977; Galai 1973). Strikes and riots began throughout the industrialized sections of Russia. These events influenced the government to make concessions. It is interesting to look at how the leader of the Bolsheviks, Vladimir Lenin, comments on that event. He says: "Thousands of workers - not SocialDemocrats, but loyal God-fearing subjects - led by the priest Gapon, streamed from all parts of the capital to its centre, to the square in front of the 
Winter Palace, to submit a petition to the tsar. The workers carried icons. In a letter to the tsar, their then leader, Gapon, had guaranteed his [the tsar's] personal safety and asked him to appear before the people" (Lenin 1964:326). In Lenin's view, the Orthodox Church could not spread revolutionary ideas to the armed forces because the Orthodox liberationists were still too naïve, their mood was too passive, too good-natured, and too Christian (Lenin 1964:244245). However, in the words of Lenin, God-fearing subjects contributed to "a movement for national liberation (which) flared up among the oppressed peoples of Russia" (Lenin 1964:249).

Archimandrite Michail Semenov, an original member of the Religious Philosophical society, defended the Social Democrats. In a series of lectures given in 1905 and 1906 and published in a small book, entitled Christian Freedom (Semenov 1906), he suggested that Karl Marx's economic theories were Christian and corresponded to the traditional teaching of the Orthodox Church (cf Cunningham 1981:315). Semenov (1906) publicly supported the opinion that the economic and social aims of Russian socialist parties should be reconciled with Orthodox Christianity. At that time, the students of the Orthodox Theological Academies held requiems for revolutionaries and publicly preached that Christ himself had been a revolutionary. Cunningham is right in concluding that "the whole church was being infected with revolutionary attitudes" (cf Cunningham 1981: 319; see also Askol'dov 1908:1-28). The Russian evangelical Protestants (a marginal group of Christians in Russia) also supported the liberation movements and shared popular revolutionary ideas. Among the Protestants, it was also common to join liberationist political parties, even socialist parties (see support for this in Nikol'skaia 2003:15).

\section{READING THE NEW TESTAMENT IN PRE- REVOLUTIONARY AND POST-REVOLUTIONARY ORTHODOX RUSSIA}

Having demonstrated that socio-critical and socio-pragmatic strands were present within Russian Christianity at the beginning of the twentieth century, I would now like to show that in Pre-Revolutionary and Post-Revolutionary Russia, there were two camps of Orthodox thinkers who contemplated antioppression issues. In their reading of the New Testament, they went beyond the more customary ecclesiastic, dogmatic and ethical issues that had traditionally been the concerns of Orthodox theology. Some combined these issues with the liberationist ideology of Russian Marxists and Socialists; others identified the liberation movements of Pre-Revolutionary Russia as an 


\section{A forecast of liberation theology in the orthodox Russia}

anti-Christian way of interpreting Christianity. Given the limited scope of this article, the overview of these questions is limited to the hermeneutic and theological reflections of only a few selected representative groups.

\subsection{Pro-liberationists}

It is helpful here to analyse the pragmatic-sociological strategy of Russian philosopher Vladimir Frantsevich Ern (1882-1917). He was one of the founders of the Vladimir Solov'ev Memorial Religious-Philosophical Society. In his works, he attempted to develop a social-religious philosophy in which he (1) appealed for theological and religious sensitivity to the social environment in Russia; (2) challenged Orthodox Christianity to overcome its socioeconomic apathy; and (3) called for limited violent expressions, such as organized work stoppage, for the purpose of enforcing demands relating to political and social issues (Ern 1905; Ern and Sventsitskii 1905a, 1905b; Ern, 1906b). In his view, sobornost' is the basis for the life of society without private ownership. His ideal of society was a religious-social entity (cf. Ern 1906a).

Ern understood that New Testament texts must be used to support claims for the personal, civil, political, economic, social and cultural rights of the people in Russia. Moreover, certain New Testament texts could be read in a way that was not limited only to theoretical ideas of the rights and freedoms of others, the requirements of morality, public order, and general socioeconomic welfare, but that these texts appeared to justify violence in rebellions, the most extreme course to be taken in an attempt to achieve reforms (Ern 1905:279-382; for an argument against such aggressive tendencies in socialism, see Streletskii, 1912:729). For example, Ern argued that the ejection from the temple of traders, with their beasts and birds for sacrifice and the scattering of their money by Christ (cf Mt 21:12; Mk 11:15; Jn 2:14) is the justification for revolt and strikes (Ern 1905:281). In his opinion, Jesus exemplified a practical approach against the economic oppression of humankind. His point is clear: the New Testament must be read as a prooftext for social and economic liberation (Ern 1905: 264-381).

It is very interesting that a similar interpretation was offered by a Russian emigré philosopher and political leader - Ivan I''in (1883-1954) just after the Russian Civil War, the armed conflict that began in 1918 between the newly formed Bolshevik (Communist) government and the moderate socialist parties - the Socialist Revolutionaries and the Mensheviks, who represented Russia's élite business and landowning class.

In commenting on Matthew 5:43-47 and Luke 6:27-27, where Jesus commands "love your enemies," and "pray for those who persecute you", Il'in 
(1993:Vol 5, 141-144) argues that Jesus refers here to an attitude of love toward only one's enemies. Il'in suggests that Jesus is not teaching in these texts to love enemies of God or enemies of the Church (Il'in 1993, vol 5:142). In his study "On the resistance to evil with power", Il'in interprets the text of John $2: 15$ by concluding that the ultimate significance of the temple cleansing is at best resistance to evil. He says that its reference to Jesus is to be meaningful for the life within the liberation project against corruption in society (Il'in 1993, vol 5:143-144). The liberating love of God was historically linked to oppressed people and the Church under the Early Soviet regime. For Il'in, it is impossible to dissociate the condition of the oppressed, economically or religiously, from the mystery of Christ. Jesus, for Il'in (1993, vol 5:142), therefore, presents Himself as the chief Liberator, and we must recognize Him as such.

We may conclude that for some Orthodox thinkers the significance of Jesus Christ lies in His example, struggling for the poor and the outcast. The Incarnation is reinterpreted to represent God's total immersion into the human history of conflict and oppression. Thus, by His words and actions, Jesus showed us how to become true sons of God - that is, by ushering in the kingdom of God by actively pursuing the liberation of the oppressed.

The Orthodox thinkers of that time stressed that Jesus as presented in the New Testament is very clear about our responsibility to the poor and oppressed. Christ's strong warning that eternal condemnation awaits those who do not feed the hungry, clothe the naked, and visit the prisoners (Mt 25:31-46) shows that the disadvantaged are not merely a peripheral concern to Him. In the parable of the Good Samaritan, Jesus taught that anybody in need is our neighbour (Lk 10:29f). In the view of Orthodox theologians, the New Testament perspective on the poor and the oppressed is such that God's people everywhere should be troubled by the poverty of the people in Russia (Akvilonov 1906:60ff; Bogoliubov 1906:146-147). They raised the following question: how can the Orthodox Church in Russia not act to help relieve the suffering of its people?

\subsection{The anti-liberationists}

After new religious formulations began to appear in Russia in the early decades of the twentieth century, some Orthodox exegetes claimed that the New Testament does not enter into social and economic problems and issues. They argued that the New Testament does indeed speak of the equality of people, but that without doubt the equality it means is a spiritual equality. They see the New Testament as teaching about liberation from evil, not about economic liberation. In their view, the message of the New Testament and the 


\section{A forecast of liberation theology in the orthodox Russia}

message of Christ are of a religious nature, not a social one; Christianity has not been the religion of the poor and the proletariat, that is of the labouring classes in society (Bogdashevskii 1906a, 1907, 1908).

The exegetic reflections of Dmitrii Bogdashevskii (Archbishop Vasilii, 1861-1933) are discussed below. For many years, Bogdashevskii was a professor of New Testament Studies at the Kiev Ecclesiastic Academy and later he became the Rector there. In recognition of his academic achievements and credentials, all three Russian Orthodox Ecclesiastic Academies appointed him Distinguished Professor of New Testament Studies (the Moscow Ecclesiastic Academy in 1914; the St Petersburg and Kazan Academies in 1915). Bogdashevskii was received into the priesthood of the Russian Orthodox Church and he earned high regard in both ecclesiastic and scholarly circles. In his biblical scholarship, he looked upon the Bible as a religious creed of Christianity that calls for the prosperity and welfare of the people through the spiritual transformation of human beings into the image of God, rather than merely through a reformation of the State's structure and social policy (Bogdashevskii 1906a:576; 1908:282).

Bogdashevskii (1906a) responded to the problems of socio-liberation ideology in his essay "The Gospel as the foundation of life: On contemporary socioeconomic issues" and in his 1909 public lecture "The Lord's beatitudes: The Gospel's truth and the 'truth' of a modern socialism" at the Kiev ReligiousEducational Society (1909). In these studies, Bogdashevskii uses the biblical material of the canonical Gospels (collectively called the Gospel), which within mainly religious-socialist-led communities was seen as an invitation to change things on the basis of the goodness and justice of God. Bogdashevskii argues that the New Testament is not aimed at giving some kind of socio-economic theory. In his writings, Bogdashevskii has faithfully advocated social justice, but has also consistently warned the Orthodox clergy and theologians about becoming too involved in secular affairs and about the dangers of Marxism.

As an example, we may refer to his interpretation of the portions of Christ's Sermon on the Mount (especially in "The Lord's Beatitudes" according to Mt 5:3-7) which Bodgashevskii saw as the clearest text countering the call for social manipulation emphasized by the Russian religious socialists. In the

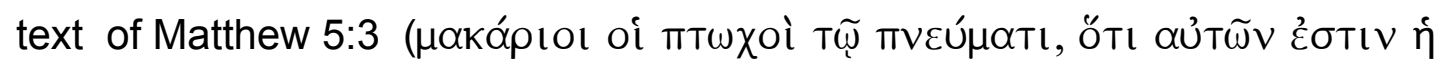

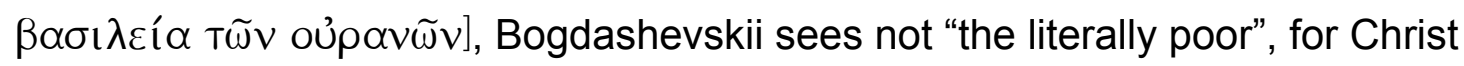
in referring to the poor added the qualification "in spirit". The main idea is that both the present and the future blessedness of the Kingdom of Heaven (i e of God) belongs to those who understand that they do not merit God's kingdom, but await God's mercy. Christ does not address the literally poor or members of the proletariat when He says that their social standing is honourable. 
"Poverty is not a Christian virtue in the same way as wealth in itself is not evil; our attitude toward poverty and wealth is important" (Bogdashevskii 1909:207, my translation). Moreover, a visible form of the Kingdom of God on Earth is the Church, and through the Church comes an implementation of this kingdom upon Earth (Bogdashevskii 1909:209). This interpretation of the text suggests that social improvement is irrelevant to this text.

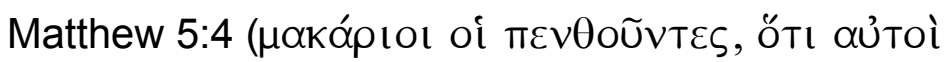

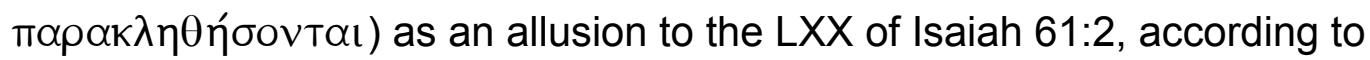
Bogdashevskii, contains political-theoretical motifs (the salvation of Jews from captivity is at hand). In Matthew, the salvation referred to stands not so much for God's activity on behalf of the literally downtrodden and poor, as it signifies God's comfort to those weeping because of their conflict with the moral captivity of sin. "If one understands the weeping as that of the downtrodden labouring classes, which are going to find comfort in a destruction of the capitalist political system, then the Gospel of Christ is replaced by the gospel of Marx" (Bogdashevskii 1909:213; cf 1908:282) (my translation).

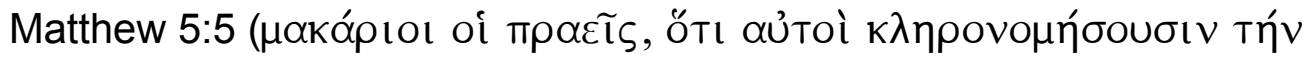
$\gamma \widetilde{\eta} v$ ) seems to be one of the most difficult of the Lord's Beatitudes that Bogdashevskii had to wrestle with. The problem for Bogdashevskii was not the interpretation of the notion of inheriting the physical earth for 1000 years on the basis of Revelation 20:4, since the book of Revelation, for Bogdashevskii, is a "symbolical book" (one that cannot be interpreted wordfor-word). Instead, the obstacle comes from a concept to understand that the meek will inherit physical possessions as the reward for being meek. Bogdashevskii argues that in verse five, Christ might possibly have pointed out the solution of the agrarian question. Nevertheless, this text says nothing in support of taking land by power; instead, earthly welfare is promised to those who are meek, not to those who are vicious, for those who are patient, not to those who go to extremes in their demands for social reforms. Christ is teaching people "be patient in suffering, do not revolt, do not be violent" (Bogdashevskii 1909:214-216).

Reference to those who hunger and thirst for righteousness in Matthew

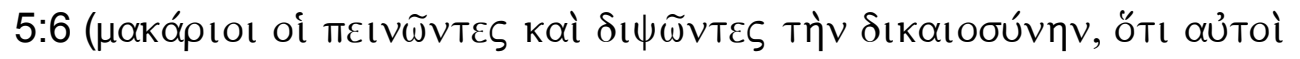
$\chi о \rho т \alpha \sigma \theta \eta ́ \sigma о \nu т \alpha \mathrm{l})$, for Bogdashevskii, must be understood in a religious sense. The hunger and the thirst for righteousness are those who are searching for holiness, seeking to live according to God's will. The righteousness, or the truth, here, is not a socialist justice, based on the abolition of private ownership. The truth has an ethical, moral, religious or even legal essence; yet this is not a text that propounds any sort of shared ownership (Bogdashevskii 1909:220-221).

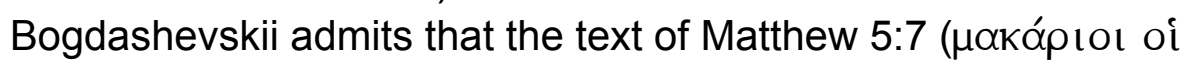

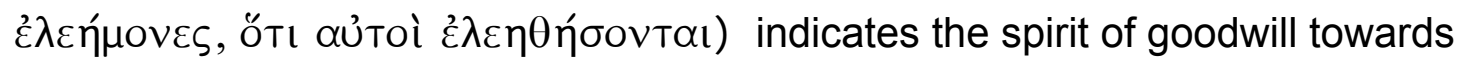
humanity, usually expressed in activities that promote human welfare (charity 


\section{A forecast of liberation theology in the orthodox Russia}

or philanthropy). Thus, the functions of religiously oriented charities are assumed. In Russian society, Bogdashevskii suggests, the voluntary sanctioned measures to aid the infirm, the poor and the disadvantaged are needed, not enforced socialist reforms (Bogdashevskii 1906b:216).

Furthermore, Bogdashevskii rejected the communist thinking that imagined a state of affairs without private ownership and that suggested that individual private property is an impediment to a just society. In his opinion, Scripture provides no basis for communal ownership. He also opposed the use of biblical testimony about the Apostolic Church in Jerusalem (cf Ac 4:32-37) as a model of a communist society characterised by the abolition of private ownership (and by its means of production, distribution and exchange). He said, "the Church is not the state and it is impossible to transform the Church ideal into the State model".

Moreover, "the Gospel does not teach a denial of private ownership" (Bogdashevskii 1906a:570; cf Bogdashevskii 1908:281-282; my translation). In Bogdashevskii's view, the New Testament does not demand the abolition of private ownership: (1) Lk 19:8-9 - Jesus stated to Zaccheus "Today salvation has come to this house, because he, too, is a son of Abraham" considering his faith, not because Zaccheus said to the Lord, "Behold, Lord, half of my possessions I will give to the poor, and if I have defrauded anyone of anything, I will give back four times as much"; (2) Acts 5:3-8 - Apostle Peter did not accuse Ananias for lying to the Holy Spirit, but rather for keeping back what remained his own and was under his control; (3) Luke 18:22 - Jesus said to a certain ruler not only "sell all that you possess, and distribute it to the poor, and you shall have treasure in heaven" but also added, "come, follow Me." This means that Christ wanted to use these men as missionaries, to whom possessions are a burden; moreover, missionaries are to "get their living from the gospel" (cf 1 Cor 9:14). This is not the call to all people, but only to a select group of travelling missionaries (Bogdashevskii 1906a:571). In light of the above interpretations, Bogdashevskii concluded, "We do not diminish the significance of the biblical virtuous model but argue that private ownership is needed as a free individual activity of man" (Bogdashevskii 1906a:571; cf 1908:282, my translation; Streletskii, 1905:204-205).

His view of a social current as a political and private power of the land and possessions is possibly ideologically and historically rooted in an ecclesiastic debate between nestiazhteli [Non-Possessors] and stiazhteli [Possessors], who, in the time of Ivan IV (1533-1584), campaigned for monastic properties, which were important for the well-being of the Orthodox Church (on this debate, see Kozakova and Lur'e 1955, and 
Klibanov, 1960). On the other hand, it is obvious that the way Bogdashevskii read the New Testament shaped his vision. The interpretation of the biblical texts related to the issue, in Bogdashevskii, however, seems to overemphasize anti-liberation tendencies. For example, his explanation of Luke 18:22, as demonstrated above, is that it records a simple call to an individual to sell his possessions before departing on a missionary "trip". Luke's idea of the kingdom of God, in this passage, stresses that a man in pursuit of eternal life needed to divest himself of all his worldly security and then follow Jesus. In this way his treasure would be securely invested in heaven and would no longer be only an earthbound asset. It shows that the underlying principle is the readiness to renounce for the sake of the kingdom of God, rather than the idea of renouncing possessions for the sake of missionary service. Still, Bogdashevskii's point is clear: The New Testament cannot be read as the proof-text for purposes of social and economic liberation, but must be interpreted in terms of ecclesiastic, dogmatic and ethical concepts (Bogdashevskii 1906a:566).

Bogdashevskii's views constitute a transposition of religious-socialist social ideas into a different hermeneutic key. Bogdashevskii sees no need for applying biblical principles to a variety of social problems engendered by industrialization. His understanding of the New Testament does not permit its reading beyond ecclesiastic, dogmatic and ethical problems. This is especially clear in his exposition of the Letter of James, which is concerned with the social effects of the rich who hurt not only themselves, but other people. Bogdashevskii intentionally avoids addressing the social problems on the basis of this Letter and underlines only the moral aspects of the issue (Bogdashevskii 1907).

The significance of the debate that Bogdashevskii leads in terms of religious-socialist propositions is that, as an Orthodox scholar, he reads the New Testament bearing in mind three dicta of the Russian Orthodox Church, namely (1) to defend the Russian monarch from revolution; (2) to respect those who are rich; (3) to bring all the social classes into unity in love and mutual respect under the umbrella of the Church. The New Testament, in his view, teaches human dignity to all social classes in Russian society. It primarily serves, however, as a religious creed of Christianity that calls for prosperity and welfare of the people through the spiritual transformation of human beings into the image of God, rather than merely through a reformation of the State's structure and social policy (cf Bogdashevskii 1906a:576; 1908:282). The New Testament's intention is "to free us from earthly vanity" (Bogdashevskii 1906a:549). It is clear that Bogdashevskii is arguing against a 
certain way of reading the biblical texts which attempts to re-discover biblical truth in order to support pragmatic versions of socio-critical theory.

\section{CONCLUSION}

During the last decades of the nineteenth century and at the start of te twentieth century, some Orthodox thinkers and theologians sought to induce the participation of the Church in the political shifts in Russia (see Leontovich 1980; Read 1977). This new realm of thought, embodied by the principles of human dignity, respecting the rights of the poor and Orthodox faith, was carried forth by Orthodox theologians, some of whom argued that Russia had to create a new political covenant with its poor citizens. Through religious praxis and faith teachings, these Orthodox exegetes and theologians also attempted to connect the suffering of Christ on earth with that of the oppressed and poor in Old Tsarist Russia, using particular references in the gospel. Although these theologians argued that, in the end, the poor will eternally celebrate in the holy kingdom of heaven, they nevertheless believed that it was equally necessary for the poor to enjoy decent human growth or development in the secular world if they were to practise their Orthodox faith (cf the conclusions of Putnam 1977).

It is possible to trace the influence of certain Marxist socio-analytical insights within Russian Christianity at the beginning of the twentieth century Of course, Orthodox thinkers would not use Marx's social insights together with his materialist and atheist interpretations. The main concern of Orthodox liberation thinking was to revitalize the service for the people, while the Church was seen as legitimate only if it rendered a service to the needy.

At the start of the twentieth century, in Russia there was a reinvention of the gospel and Jesus Christ to reflect the harsh political and socioeconomic realities of the Russian Empire (see Read 1977). Of course, the original religious-liberationist current of Russian Orthodox thought was overrun by other secular currents, reactionary and revolutionary. On the one hand, within the Orthodox Church, there was no unity on many of the issues being debated. On the other hand, the ideology of the Russian Bolshevik Revolution was not defined by the Gospel current. Although there was a conception of Christ as a political figure, a revolutionary, Orthodox thinkers foresaw and had forebodings about the Russian Revolution, and they anticipated its catastrophic potential in their thinking (Fedotov 1957). Nevertheless, a few years after the Bolshevik Revolution, Berdyaev expressed regret that the Church had been totally passive within the Russian Revolution, and that Russian Christianity had played merely a role of sufferance (Berdyaev 1925). 
During the last decades of the nineteenth century and at the start of the twentieth century, the theological positions of Orthodox thinkers touched on the issues of a holistic vision of God's redeeming activity in the midst of the current reality faced by the Russian people. In a situation where justice had been long neglected, the Russian Orthodox theology was at the forefront of a reaching for new horizons of understanding in the pursuit of a just peace and of the reconciliation proclaimed in the Gospel of Jesus Christ. It seems that mainly because of their fear of a purely atheist revolutionary movement in Russia, Orthodox theologians did not develop their programme into a final format and were forced to stress that Christianity is not revolutionary in the outward sense of the word.

Further studies can and should be done to analyse the theological system of socio-critical and socio-pragmatic strands in Russian theology at the start of the twentieth century. The observations made in this article on the development of these strands among Orthodox-religious socialists suggest that, in a limited sense, in Russia about a century ago there was an earlier version of so-called Liberation Theology.

\section{Works consulted}

Akvilonov, E 1906. Khristiantvo i sotsial-demokratiia. Tsrkovnyi Golos [Christianity and social democracy] Khristianskoe Chtenie 1, 60-69.

Alexyev, N N 1930. Religia, pravo i nravstvennost. [Religion, law and morality.] Paris.

Askol'dov, S L 1908. Staroe i novoe religioznoe soznanie [On old and new religious conscience]. The notes of St Petersburg Philosophical Society. St Petersburg.

Berdyaev, N 1925. The kingdom of God and the kingdom of Caesar [Tsarstvo Bozhie i Tsarstvo Kesarya] Journal Put' 1, 31-52.

Berdyaev, N 1935. Personalizm i Marksizm [Personalism and Marxism] Put' July/September 48, 3-19.

Berdyaev, N 1937. The origin of Russian Communism. London: G Bles.

Berdyaev, N 1946. Russkaia ideia: osnovnye problemy russkoi mysli XIX veka i nachala $X X v$ [Russian idea: The basic problems of Russian thought XIX $c$. and beg. $X X$ c.]. Paris: YMCA Press.

Berdyaev, N 1989. Tipy religioznoi mysli v Rossii [The types of religious thought in Russia]. Paris: YMCA Press.

Bogdashevskii, D I 1906a. Evangelie kak Osnova Zhizni: po povodu sovremennykh sotsial'no-ekonomicheskikh voprosov. [The Gospel as the foundation of Life: on the contemporary social-economic issues] TKDA I(4), 547-576.

Bogdashevskii, D I 1906b. Chtenie. O Lichnosti Ap. Pavla [Lecture. On the personality of St Paul] TKDA I(1), 1-16.

Bogdashevskii, D I 1907. Poslanie Apostola lakova [The letter of James] TKDA 3(10), 181-210.

Bogdashevskii, D I 1908. Chtenie. Sovremennye vragi kresta Khristova [Lecture. The modern enemies of Christ's cross] TKDA 3(10), 273-285.

Bogdashevskii, D I 1909. Blazhenstva Gospodni: Evangel'skaia pravda i 'pravda' covremennogo sotsializma [The Lord's beatitudes: the Gospel's truth and a "truth" of a modern socialism] TKDA I(2), 203-236. 
Bogoliubov, D 1906. Khristiantvo i sotsial-demokratiia [Christianity and social democracy] Tsrkovnyi Golos [Church's voice]. 5, 146-147.

Bronnikova, E B 1993. Petersburg Philosophical Society. The philosophical questions.

Bulgakov, S 1968. Ot marksizma k idealizmu, sbornik statei (1896-1903) [From Marxism to Idealism. Collection of Articles (1896-1903)]. Frantfurt: Posev.

Bulgakov, S 1906. Religiia i politika [Religion and Politics] Poliarnaia zvezda, 118127.

Bulgakov, S 1991. Khristianskii Sotsializm [Christian Socialism] Novosibirsk. Nauka.

Christoff, P K 1961. An introduction to nineteenth century Russian Slavophilism. Gravenhage: Mouton \& Co.

Cunningham, J W 1981. A vanished hope: The movement for church renewal in Russia, 1905-1906. Crestwood: St Vladimir Seminary Press.

Curtiss, J S 1940. Church and state in Russia: The last years of the empire 19001917. New York: Columbia University Press.

Edmondson, L 1984. Feminism in Russia, 1900-1917. Stanford: Stanford University Press.

Ern, V 1905. Khristianskoe uchenie o sobstvennosti [Christian teaching on private ownership]. Voprosy Zhisni [The Questions of Life] 8-9.

Ern, V 1906a. Khristianskoe uchenie o sobstvennosti [Christian teaching on private ownership]. Moscow.

Ern, V 1906b. Tserkovnoe vozrozhdenie [Church Revival]. Voprosy Religii [The Questions of Religion].

Ern, V \& Sventsitskii, V 1905a. Veruyushchie protiv samoderzhaviia [Beliveres against the Tzaristm] Osvobozhdenie [Liberation] 68.

Ern, V \& Sventsitskii, V 1905b. Veruyushchie protiv samoderzhaviia [Beliveres against the Tzaristm] Osvobozhdenie [Liberation] 73.

Fedorov, N 1995-2000. Sobranie sochinenii v chetyrekh tomakh [Works 4 vols]. Moskva: Progress.

Fedotov, G 1957. Khristianin v Revolutsii [The Christian in revolution]. Paris.

Florovsky, G 1979. Ways of Russian theology, Part Two. Belmont, MA: Nordland.

Frank, S L 1988. Dukhovnye Osnovy Obschtestva [The spiritual foundations of society]. New York: Posev.

Galai, S 1973. The liberation movement in Russia, 1900-05. Cambridge: Cambridge University Press.

Gutierrez, G 1973. A theology of liberation: History, politics and palvation. Maryknoll, NY: Orbis Books.

Jordan, S 1986. Bibliography: Latin American Liberation Theology since 1976, Modern Churchmen 28, 32-39.

Il'in, I 1993. Sobranie sochinenii v 10 tomakh [Collected Works, 10 Vols]. Moskva: Russkaia kniga.

Kartashov, A 1908. Zapiski St. Peterburgskogo filosofskogo obshchestva [The notes of St Petersburg Philosophical Society]. St Petersburg.

Khomiakov, A 1900-1906. Sobranie sochinenii v 8 tomakh [Collected Works. 8 Vols]. Moskva.

Klibanov, A 1960. Reformatsionnye dvizheniia v Rossii v XIV-pervoi polovine XVI v. [The Reformational Movements in Russia: 14-16 cc.] Moscow. 
Kozakova, N \& Lur'e Y 1955. Antifeodal'noe ereticheskoe dvizhchenie na Rusi XIV - nachala XVI veka [The Antifeudal Movements in Russia: 14-16 $c c]$. Moskva: Isd-vo Akademii nauk SSSR.

Kratirov, P 1916. Sotsilizm i Khristianskvo v ikh vzaimnykh otnosheniyakh [Socialism and Christianity in their interrelationships] Vera i Razum [Faith and Reason] 8-9.

Lenin, V 1964. Lecture on the 1905 revolution, in Collected Works, Vol 23. Translated by M S Levin and others. Moscow: Progress Publishers.

Leontovich, V 1980. Istoriia liberalizma $v$ Rossii, 1762-1914 [History of liberation in Russia]. Paris: YMCA Press.

Losskii, N 1952. History of Russian philosophy. London: G Allen and Unwin.

Nikol'skaia, T 2003. Russkii protestantism i gosudarstvennaia vlast' v 1905-1991 gg [Russian protestantism and State authority: 1905-1991]. St Petersburg: European University.

Pipes, R 1970. Struve: A liberal on the left, 1870-1905. Cambridge, MA: Harvard University Press.

Pipes, R 1990. The Russian revolution. New York: Vintage.

Polozov, A 1903. Ekonomicheskii materialism i religiia [Economic materialism and religion]. Vara i Tserkov' [Faith and Church] 3-5.

Putnam, G 1977. Russian alternatives to Marxism. Knoxville, TN: University of Tennessee Press.

Read, C 1977. Religion and revolution in Russia, 1900-1912: The Vekhi debate and its intellectual background. London: Macmillan.

Rowland, C ed 1999. Liberation theology. Cambridge: Cambridge University Press.

Segundo, J L 1976. The liberation of theology. Maryknoll, NY: Orbis Books.

Simon, G 1973. Church, state and society, in G Katkov et al (eds), Russia enters the twentieth century. London: Tample Smith Ltd.

Spektorskii, N 1925. Khristianstvo i Kultura [Christianity and culture] Prague.

Stepun, F 1936. The Russian soul and revolution. London: C Scribner's sons.

Stites, R 1991. The women's liberation movement in Russia: Feminism, nihilism, and bolshevism, 1860-1930. Princeton, NJ: Princeton University Press.

Streletskii, N 1904. Sotsizlim- ego istriia i kriticheskaia otsenka s khristiankoi tochki zreniia [Socialism - its history and critical evaluation from the Christian point of view]. TKDA 12.

Streletskii, N 1905. Sotsizlim- ego istriia i kriticheskaia otsenka s khristiankoi tochki zreniia [Socialism - its history and critical evaluation from the Christian point of view]. TKDA 6.

Streletskii, N 1912. Revoliutsionniy kharakter socializma [Revolutionary character of socialism]. Vera i Rasum [Faith and Reason] 6.

Ternavtsev, V A 1906. The Russian church in front of a great task. The notes of the religious-philosophical meetings in St Petersburg: 1902-1903. St Petersburg.

Verhovskoy, S ed 1953. Pravoslavije v Zhizni [Orthodoxy in life]. New York.

Vyascheslavtzev, V 2002. Eternal in Russian philosophy. Grand Rapids, MI: Wm B Eerdmans.

Zen'kovsky, V 1952. Nasha Epokha [Our era]. Paris: Religiozno-pedagog. kabinet pri Pravoslavnom Institute.

Zen'kovsky, V 1991. Istoriia russkoi filosofi. [The history of Russian philosophy]. 2 Vols. Leningrad: Ego. 